\title{
Krim ekstrak teh hijau 20\% (Camellia sinensis) mencegah peningkatan jumlah melanin sama efektif dengan krim hidrokuinon $4 \%$ pada kulit marmut (Cavia porcellus) yang dipajan sinar ultraviolet B
}

\author{
${ }^{1}$ Putri Puspitasari, ${ }^{2}$ AAg Putra Wiraguna, ${ }^{3}$ Wimpie Pangkahila
}

\author{
${ }^{1}$ Program Pascasarjana Anti-Aging Medicine \\ ${ }^{2}$ Departemen Penyakit Kulit dan Kelamin \\ ${ }^{3}$ Departemen Andrologi dan Seksologi \\ Fakultas Kedokteran Universitas Udayana Denpasar \\ E-mail: putri.puspitasari86@gmail.com
}

\begin{abstract}
This study was aimed to evaluate the effectiveness of $20 \%$ green tea extract in preventing the increase of melanin in guinea pig skin exposed to UV-B and to compare the effectiveness of this treatment to $4 \%$ hydroquinone cream. This was an experimental study with the post-test only control group design. Subjects were four groups; each consisted of 7 male guinea pigs. Group 1, the control group, was exposed to UV-B only. Group 2 was exposed to UV-B and applied with cream based substance. Group 3 was exposed to UV-B and applied with $4 \%$ hydroquinone cream. Group 4 was exposed to UV-B and applied with $20 \%$ green tea extract. The total UV-B intensity was $390 \mathrm{~mJ} / \mathrm{cm}^{2}$ consistently exposed for two weeks. Histopathological slides of the skin tissue were stained with Masson Fontana technique. The total amount of melanin was calculated in percentage of pixel compared to pixel of melanin in total epidermis. The results showed that the highest amount of melanin was in group $1(24.44 \%)$ and the lowest amount of melanin was in group $3(1.04 \%)$ meanwhile the amount of melanin in group $4(1.34 \%)$ was nearly the same with group 3 . There were significant differences between group 1 to group 3 and $4(P<0.05)$. There was no significant difference between group 3 and group $4(P>0.05)$. Conclusion: The $20 \%$ green tea extract was as effective as $4 \%$ hydroquinone cream in inhibiting the increase of melanin in guinea pigs'skin exposed to UV-B.
\end{abstract}

Keywords: green tea extract, melanin, ultraviolet B

\begin{abstract}
Abstrak: Penelitian ini bertujuan untuk mengetahui efek pemberian krim ekstrak teh hijau $20 \%$ terhadap peningkatan jumlah melanin pada kulit marmut yang dipajan sinar UVB serta membandingkan efektivitasnya dengan krim hidrokuinon $4 \%$. Jenis penelitian ialah eksperimental murni dengan post test only control group design. Subyek penelitian terdiri dari empat kelompok dengan 7 ekor marmut jantan setiap kelompok. Kelompok 1 (kelompok kontrol) diberi pajanan sinar UV-B saja. Kelompok 2 diberi pajanan sinar UV-B dan diolesi krim dasar. Kelompok 3 diberi pajanan sinar UV-B dan krim hidrokuinon 4\% sedangkan kelompok 4 diberi pajanan sinar UV-B dan krim ekstrak teh hijau 20\%. Dosis total UVB yaitu $390 \mathrm{~mJ} / \mathrm{cm}^{2}$ diberikan selama 2 minggu. Sediaan histopatologik jaringan kulit dipulas dengan pewarnaan Masson Fontana. Jumlah melanin dihitung dengan persentase pixel luas area melanin dibandingkan dengan pixel seluruh jaringan epidermis. Hasil penelitian menunjukkan jumlah melanin tertinggi pada kelompok $1(24,44 \%)$ dan terendah pada kelompok $3(1,04 \%)$. Jumlah melanin pada kelompok $4(1,34 \%)$ hampir sama dengan kelompok 3. Terdapat perbedaan bermakna antara kelompok 1 dengan kelompok 3 dan $4(P<0,05)$. Perbandingan antara kelompok 3 dan 4 tidak berbeda bermakna dalam mencegah peningkatan jumlah melanin $(P>0,05)$. Simpulan: Pemberian krim ekstrak teh hijau $20 \%$ sama efektif dengan krim hidrokuinon $4 \%$ dalam mencegah peningkatan jumlah melanin kulit marmut yang dipajan sinar UV-B.
\end{abstract}

Kata kunci: krim ekstrak teh hijau, melanin, ultraviolet B 
Penuaan merupakan proses alamiah yang terjadi pada setiap manusia, serta tidak dapat dihentikan. Kulit merupakan organ yang menunjukkan tanda-tanda penuaan secara nyata. Tanda itu terjadi akibat akumulasi kerusakan endogen yang disebabkan oleh pembentukan ROS (reactive oxygen species) secara terusmenerus dari metabolisme oksidasi seluler. ${ }^{1}$

Salah satu tanda penuaan pada kulit ialah proses hiperpigmentasi yang dapat disebabkan oleh peningkatan jumlah melanin di epidermis (pada kasus lentigo), dan di epidermis serta dermis bagian atas (pada kasus melasma). ${ }^{2,3}$ Pada penelitian in vitro, setelah terpajan sinar UV melanin dapat membentuk hidrogen peroksida dan anion superoksida yang dapat menyebabkan mutasi pada melanosit maupun sel lainnya. ${ }^{4}$ Proses pembentukan melanin di melanosom bermula dari hidroksilasi Ltirosin menjadi L-dopa dan oksidasi Ldopa menjadi dopakuinon; kedua proses ini memerlukan aktivitas dari enzim tirosinase. Dopakuinon akan dipolimerisasi secara spontan membentuk melanin. Enzim tirosinase akan bekerja langsung pada saat distimulasi oleh sinar UV. Paparan sinar ultraviolet A (UV-A) dengan panjang gelombang 320-400 nm menghasilkan intermediate pigmentary darkening. Pada proses pembentukan melanin di melanosom, terdapat peningkatan aktivitas enzim tirosinase, penambahan jumlah sel melanosit dan peningkatan distribusi melanin ke keratinosit; pigmentasi ini mulai terjadi 2-3 hari setelah paparan dan bertahan selama 10-14 hari. $^{3}$

Bahan pemutih kulit yang bekerja sebagai inhibitor tirosinase telah banyak digunakan dalam bahan kosmetik sebagai pencegah hiperpigmentasi. Walaupun krim hidrokuinon $4 \%$ merupakan baku emas pengobatan hiperpigmentasi namun pada penggunaan jangka panjang hidrokuinon menimbulkan banyak efek samping seperti okronosis sehingga saat ini mulai dibatasi penggunaannya. Berdasarkan hal tersebut, maka perlu dicari bahan-bahan anti hiperpigmentasi lain yang bersifat alami dengan efek samping yang lebih sedikit. ${ }^{5,6}$
Teh hijau (Camellia sinensis) mengandung polifenol yang berperan sebagai antioksidan yang baik untuk kesehatan. ${ }^{7}$ Penelitian menunjukkan bahwa epigallocatechin 3-0-gallate (EGCG) yang merupakan salah satu derivat polifenol, mampu menurunkan aktivitas tirosinase, terutama komponen EGCG, EGC, dan CG yang mempunyai daya hambat terhadap terjadinya pigmentasi karena pajanan UVB. ${ }^{8}$

Ekstrak daun teh hijau merupakan kandidat bahan anti hiperpigmentasi yang potensial. Telah diketahui bahwa teh hijau mempunyai daya hambat tirosinase yang kuat dan telah dibuktikan bahwa teh hijau mempunyai efek antiinflarnasi dan anti karsinogenik yang dapat digunakan untuk mengatasi berbagai gangguan kulit. Senyawa aktif utama teh hijau yang bertanggung jawab terhadap aktivitas ini ialah EGCG. Ekstrak teh hijau (Camellia sinensis) yang diambil dari Perkebunan Teh PPTK, Bogor, Jawa Barat telah dilakukan analisis fitokimia dan ditemukan kandungan fenol $1015,99 \mathrm{mg} / 100 \mathrm{~g}$ GAE, tannin $1334,78 \mathrm{mg} / 100 \mathrm{gTAE}$, dan flavonoid $605,48 \mathrm{mg} / 100 \mathrm{~g} / \mathrm{QE}$.

\section{METODE PENELITIAN}

Jenis penelitian ini ialah eksperimental dengan post test only control group design. Penelitian ini menggunakan marmut jantan strain lokal, umur tiga bulan, berat 300-350 gram, dibagi menjadi empat kelompok masing-masing berjumlah 7 ekor marmut. Kelompok 1 sebagai kelompok kontrol diberikan pajanan sinar UVB saja; kelompok 2 diberikan pajanan sinar UVB dan krim dasar; kelompok 3 diberikan pajanan sinar UVB dan krim hidrokuinon 4\%; dan kelompok 4 diberikan pajanan sinar UVB dan krim ekstrak teh hijau $20 \%$.

Setiap kelompok diberi pajanan sinar UVB sebanyak 3 kali seminggu yaitu hari Senin, Rabu, dan Jum'at selama dua minggu. Setiap pajanan diberikan dosis 65 $\mathrm{mJ} / \mathrm{cm}^{2}$ selama 65 detik. Pada hari pemajanan UVB, pada setiap kelompok dioleskan krim 20 menit sebelum dan 4 jam sesudah pajanan sinar UVB. Pada hari 
tanpa pemajanan UVB, krim tetap dioles 2 kali sehari.

Empat puluh delapan jam setelah pajanan terakhir, marmut dieutanasia dengan terlebih dahulu menggunakan ketamin dosis berlebih (100 $\mathrm{mg} / \mathrm{kg} \mathrm{BB})$ secara intraperitoneal. Daerah punggung yang akan diambil kulitnya, dibersihkan dari bulu kemudian dibuat preparat histopatologik menggunakan pulasan Masson Fontana yang memberikan warna hitam pada melanin. Jumlah melanin dihitung dengan persentase pixel luas area melanin dibandingkan dengan pixel seluruh jaringan epidermis.

Penelitian ini menggunakan uji normalitas data, uji homogenitas data, uji komparabilitas, dan uji efek perlakuan.

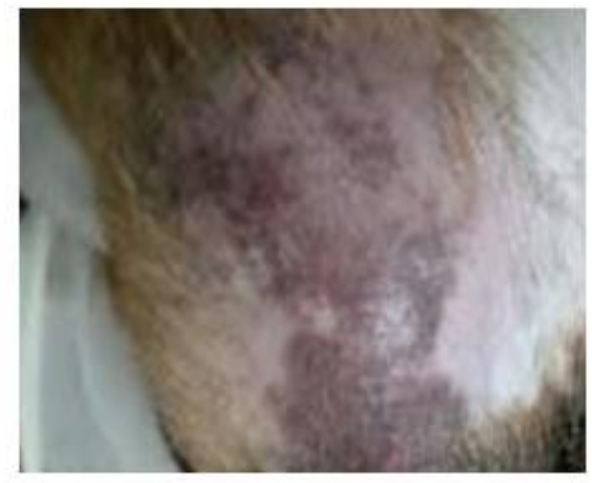

Kelompok 1

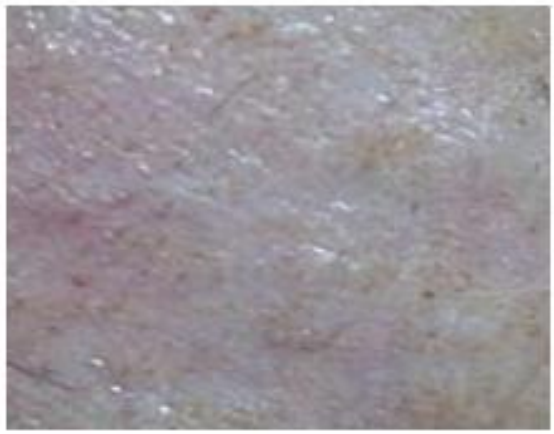

Kelompok 3

\section{HASIL DAN BAHASAN}

Setelah dua minggu perlakuan, didapatkan gambaran klinis kulit marmut yang diamati secara makroskopik (Gambar 1) kemudian jaringan kulit punggung marmut dibiopsi untuk dilakukan pemeriksaan histopatologik. Melanin tampak berwarna hitam pada pewarnaan MassonFontana (Gambar 2).

Hasil penelitian menunjukkan rerata jumlah melanin sebagai berikut: kelompok 1 sebesar 24,44 $\pm 2,40 \%$; kelompok 2 sebesar

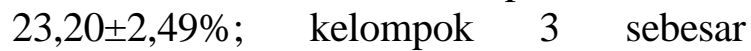
$1,04 \pm 0,32 \%$; dan kelompok 4 sebesar $1,34 \pm 0,41 \% \quad(P<0,05)$, yang berarti terdapat perbedaan rerata kadar melanin antar kelompok perlakuan (Tabel 1).

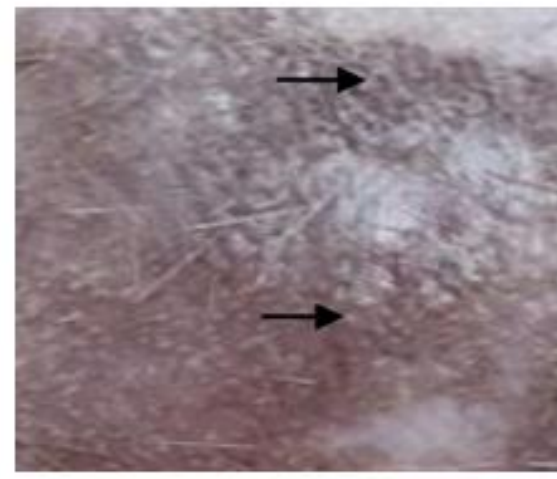

Kelompok 2

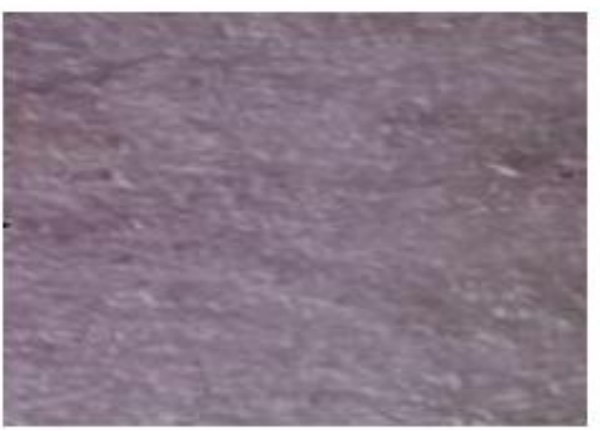

Kelompok 4

Gambar 1. Gambaran klinis kulit marmut setelah perlakuan dinilai dengan adanya hiperpigmentasi pada kulit marmut. Pada kelompok 1 (dipajan dengan sinar UVB tanpa krim apapun) terlihat lesi hiperpigmentasi kehitaman yang luas; pada kelompok 2 (krim dasar) tampak lesi hiperpigmentasi kehitaman samar (anak panah); pada kelompok 3 (hidrokuinon 4\%) terlihat lesi hiperpigmentasi paling sedikit; pada kelompok 4 (krim ekstrak teh hijau 20\%) terlihat lesi hiperpigmentasi coklat samar. 


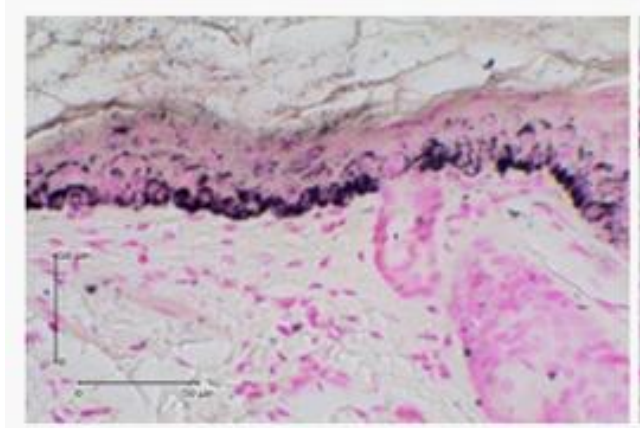

Kelompok 1

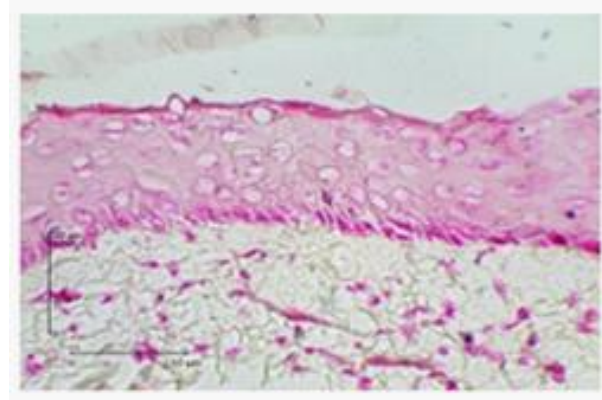

Kelompok 3

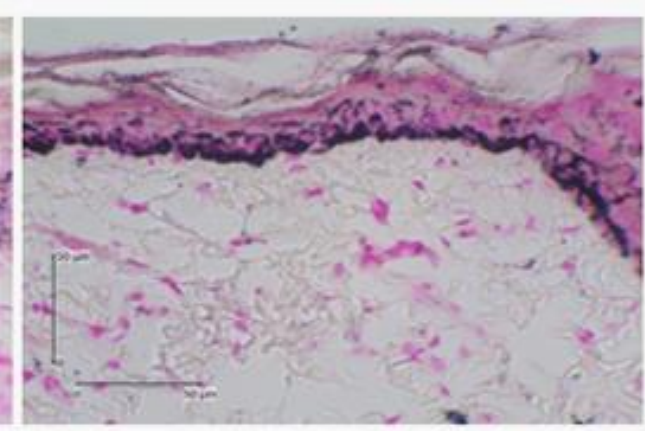

Kelompok 2

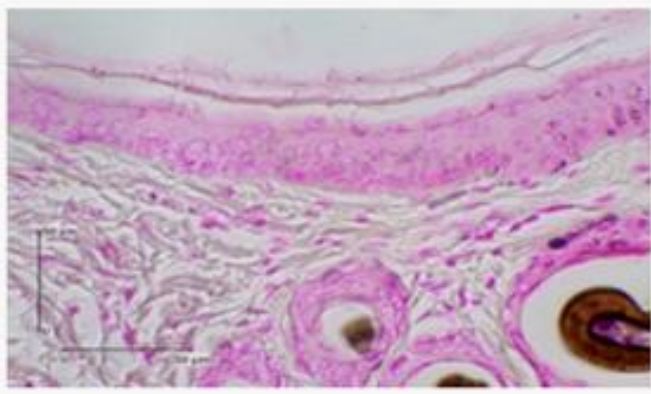

Kelompok 4

Gambar 2. Gambaran melanin kulit marmut dengan pulasan Masson Fontana. Histopatologik jaringan epidermis kulit marmut dengan pembesaran 400x. Kelompok 1 diberikan pajanan UV-B tanpa krim apapun, tampak melanin berwarna coklat/hitam yang padat pada jaringan epidermis. Kelompok 2, diberikan pajanan UVB dan bahan dasar krim, tampak melanin berwarna coklat kehitaman yang padat pada jaringan epidermis. Kelompok 3, diberikan pajanan UV-B dan krim hidrokuinon 4\%, tampak melanin berwarna hitam yang tidak berkelompok dan tidak padat di basal epidermis dan sedikit menyebar ke lapisan atas epidermis. Kelompok 4, diberikan pajanan UV-B dan krim ekstrak teh hijau 20\%, tampak melanin berwarna hitam sedikit berkelompok dan sedikit menyebar ke lapisan atas epidermis.

Tabel 1. Perbedaan jumlah melanin antar kelompok sesudah perlakuan

\begin{tabular}{cccccc}
\hline Kelompok subjek & n & Jumlah melanin (\%) & SB & $\boldsymbol{F}$ & $\boldsymbol{P}$ \\
\hline Kelompok 1 & 7 & $24,44^{\mathrm{a}}$ & 2,4 & & \\
Kelompok 2 & 7 & $23,20^{\mathrm{a}}$ & 2,49 & 390,107 & 0,001 \\
Kelompok 3 & 7 & $1,04^{\mathrm{b}}$ & 0,32 & & \\
Kelompok 4 & 7 & $1,34^{\mathrm{b}}$ & 0,41 & & \\
\hline
\end{tabular}

Keterangan: Notasi yang sama menunjukkan tidak berbeda $(P>0,05)$, sedangkan notasi yang berbeda $(\mathrm{a}, \mathrm{b})$ menunjukkan berbeda bermakna, dianalisis dengan Least Significance Difference (LSD)

Rerata jumlah melanin kelompok 1 dan kelompok 2 tidak berbeda bermakna $(P>$ $0,05)$; begitu pula dengan rerata jumlah melanin kelompok 3 dan kelompok 4 tidak berbeda bermakna $(P>0,05)$.

Rerata jumlah melanin kelompok 1 dan kelompok 3 memiliki perbedaan rerata sebesar 23,40\% $(P<0,05)$ sedangkan rerata jumlah melanin kelompok 1 dan kelompok 4 memiliki perbedaan rerata sebesar 23,10\% $(P<0,05)$.

Rerata jumlah melanin kelompok 2 dan kelompok 3 memiliki perbedaan rerata sebesar 22,16\% $(P<0,05)$, dan rerata jumlah melanin kelompok 2 dan kelompok 4 memiliki perbedaan rerata sebesar 21,86 $(P<0,05)$.

Paparan sinar UV-B pada kulit dapat menurunkan efek antioksidan endogen pada semua lapisan kulit seperti 
glutathione (GSH), superoxide dismutase (SOD), catalase, serta ubiquinol, ${ }^{9}$ dan juga menghasilkan radikal bebas seperti hidrogen peroksida, anion superoksida, dan nitrik oksida (NO) sehingga dapat terbentuk ROS. ${ }^{10}$ Kerusakan kulit yang disebabkan oleh paparan sinar matahari sangat tergantung dari seberapa sering dan lamanya paparan, jenis sinar UV serta jumlah melanin di kulit (tipe kulit seseorang). Gejala klinis dapat terjadi karena photoaging seperti kerutan dan hiperpigmentasi. ${ }^{9}$

Radiasi sinar UV menyebabkan pigmentasi dengan beberapa cara yaitu meningkatkan kerja enzim melanogenik, kerusakan DNA yang akan menstimulasi melanogenesis, meningkatkan transfer melanosom menuju keratinosit, dan meningkatkan aktivitas dendritik sel melanosit. $^{11}$ Radiasi sinar UV dapat memicu terjadinya ROS yang selanjutnya memicu keluarnya NO, protein kinase, melanocyte stimulating hormone (MSH), dan PGE2 yang dapat merangsang terjadinya proses melanogenesis yang dapat memicu terbentuknya melanin oleh melanosit. $^{12}$

Hidrokuinon merupakan baku emas untuk terapi hiperpigmentasi/melasma, ${ }^{5,13}$ serta mempunyai mekanisme kerja dengan cara menghambat enzim tirosinase, merusak melanosit secara langsung, mempercepat degradasi melanosom, dan menghambat sintesis enzim melanogenesis. ${ }^{6}$ Hidrokuinon dapat menurunkan lesi hiperpigmentasi hingga $90 \%$ dengan mencegah peningkatan jumlah melanin pada lapisan epidermis. ${ }^{5}$ Penggunaan hidrokuinon jangka panjang dapat menimbulkan efek samping berupa okronosis. Terjadinya okronosis disebabkan oleh penggunaan obat-obatan yang membentuk substansi lir asam homogenistik polimer selama metabolismenya yang tampak sebagai hiperpigmentasi asimtmatik pada wajah, leher, punggung, dan tungkai. Pada pemeriksaan histopatologik ditemukan sekumpulan globul coklat kekuningan (ochronotic) pada pars papilaris dermis. Okronosis eksogen biasanya terjadi setelah penggunaan obat anti malaria, produk mengandung resorsinol, fenol, air raksa, dan picric acid. ${ }^{2}$

Berdasarkan penelitian in vitro yang dilakukan Thi et al. ${ }^{14}$ ekstrak teh hijau mengandung flavonoid yang memiliki aktifitas biologis sebagai inhibitor tirosinase. Telah diketahui bahwa inhibitor tirosinase yang terdapat pada flavonoid bersifat kompetitif, yaitu akan berikatan langsung dengan enzim bebasnya. Oleh karena itu kandungan yang terdapat pada ekstrak teh hijau berkemampuan untuk mencegah peningkatan pembentukan melanin akibat pajanan sinar UV-B.

Polifenol yang terdapat pada teh hijau juga mempunyai efek melindungi kulit dari radiasi UV sehingga gangguan kulit atau kanker kulit tidak terjadi. Polifenol memiliki efek anti inflamasi, imunomodulator, memperbaiki DNA yang rusak, memperbaiki fungsi sel, ${ }^{9}$ dan sebagai fotoprotektif. $^{15}$ Adanya polifenol dapat menghambat terjadinya proses melanogenesis, sehingga peningkatan jumlah melanin tidak terjadi. Polifenol yang dimaksudkan pada penelitian ini terbatas pada polifenol secara umum saja dan tidak diketahui dengan pasti bagian mana dari polifenol tersebut yang berperan karena keterbatasan fasilitas.

Tannin bersifat sebagai antioksidan dan juga mempunyai kemampuan sebagai anti tirosinase, ${ }^{16}$ sehingga proses biosintesis melanin dapat dihambat dan peningkatan produksi melanin tidak terjadi setelah pajanan sinar UVB.

Sejauh ini penghambatan tirosinase yang paling sering digunakan pada pengobatan gangguan pigmentasi kulit, namun masih sangat sedikit yang memiliki aplikasi praktis karena formulasi dan efek samping yang dapat timbul akibat pemakaian jangka panjang. Mengingat proses pigmentasi kulit sangat kompleks maka diperlukan terapi kombinasi agar dapat memenuhi aspek integral dari pengobatan kelainan pigmentasi kulit.

\section{SIMPULAN}

Berdasarkan hasil penelitian ini dapat 
disimpulkan bahwa pemberian krim ekstrak teh hijau $20 \%$ (Camellia sinensis) sama efektif dengan krim hidrokuinon $4 \%$ dalam mencegah peningkatan jumlah melanin pada marmut (Cavia Porcelus) yang dipajan sinar UV-B

\section{DAFTAR PUSTAKA}

1. Gilchrest BA, Krutmann J. Skin Aging. Berlin: Springer-Verlag, 2006; p. 10312.

2. Lapeere H, Boone B, Schepper SD, Verhaeghe E, Ongenae K, Geel NV. Hypomelanosis and hyper-melanosis. In: Wolf K, Goldsmith LA, Katz GS., Gilchrest BA, editors. Fitzpatricks Dermatology in General Medicine Vol 1 (7th ed). New York: McGraw Hill, 2008; p 623-40.

3. Baumann L, Saghari S. Skin pigmentation and pigmentation disorders. In Baumann L, Saghari S, Weisberg E, editors. Cosmetic Dermatology (2nd ed). New York: McGraw Hill, 2009; p. 98-106.

4. Brenner M, Hearing VJ. The protective role of melanin against UV damage in human skin. Photochem Photobiol. 2008;84(3):539-49.

5. Baumann L, Alleman IB. Depigmentation agent. In: Baumann L, Saghari S, Weisberg E, editors. Cosmetic Dermatology (2nd ed). New York: McGraw Hill, 2009; p. 280-8.

6. Bruce S. Safety and efficacy of a novel multimodality hydroquinone - Free skin brightener over six months. J Drugs Dermatol. 2013;12(3):S27-31.

7. Syah ANA. Taklukkan Penyakit dengan Teh Hijau. Jakarta: AgroMedia Pustaka, 2006.

8. Chiu AE, Chan JL, Kern DG, Kohler S, Rehmus WE, Kimball AB. Doubleblinded, placebo-controlled trial of green tea extracts in the clinical and histologic appearance of photoaging skin. Dermatol surg. 2005;31:855-9.

9. Pandel R, Poljsak B, Godic A, Dahmane R. Skin photoaging and the role of antioxidants in its prevention. ISRN Dermatology. 2013;2013. Article ID 930164.

10. Ichihashi M, Ando H, Yoshida M, Niki Y, Matsui M. Photoaging of the skin. J Anti Aging Med. 2009;6(6): 46-59.

11. Kindred C, Halder RM. Pigmentation and skin of color. In: Draelos ZD, editor. Cosmetic Dermatology Products and Procedures (1st ed). New Jersey: Wiley-Blackwell, 2010; p. 27-35.

12. Costin GE, Hearing VJ. Human skin pigmentation: Melanocytes modulate skin color in response to stress. 2007. [cited 2014 May 6]. Available from: http://www.fasebj.org/content/ 21/4/976.full.

13. Victor FC, Gelber J, Rao B. Melasma: a review. J Cutan Med Surg. 2004;8(2):97-102

14. Thi N, Mai T, Nguyen $X$, Hai $D$, Hoang $P$, Nguyen $\mathbf{P}$, et al. Three new geranyl aurones from the leaves of Artocarpus altilis. Phytochem Lett. 2012;5(3):647-650

15. Adhami VM, Afaq F, Ahmad $\mathbf{N}$. Suppression of ultraviolet B exposure mediated activation of NF-kappa B in normal human keratinocyte by resveratol. Neoplasia. 2003;5(1):7482.

16. Feng HL, Tan L, Chai WM, Chen XX, Shi Y, Gao YS, et al. Isolation and purification of condensed tannins from flamboyant tree and their antioxidant and antityrosinase activity. Appl Biochem Biotechnol. 2014;173(1): 179-92 